\title{
A THEORETICAL STUDY TO DETERMINE COOLING LOAD OF PROPOSED BI- LEVEL BUILDING BASED ON CLTD METHOD
}

\section{PIYUSH TYAGI ${ }^{1 *} \&$ VARDAN PARASHAR ${ }^{2}$}

${ }^{I}$ M. Tech Scholar, Department of Mechanical Engineering, R.D. Engineering College, Ghaziabad, Uttar Pradesh., India

${ }^{2}$ Associate Professor, Department of Mechanical Engineering, R.D. Engineering College, Ghaziabad, Uttar Pradesh., India

\begin{abstract}
Continuous increase in atmospheric temperature because of global warming has caused reduction in human comfortness and to cope up with increasing global temperature or to achieve previous level of comfortness huge spending has to be done in form of air conditioning devices. To solve the above aforementioned problem, we have two alternatives electrical air conditioning and central air conditioning but electrical air conditioning will further increase the monetary spending because central air conditioning has high-power consumption and shorter duration of life. On the other hand, the effective design of centralized air conditioning system or a chiller unit will provide low consumption of electricity, minimal capital cost and will improve comeliness of a building. Central air conditioning can even solve the problem of oversizing and under sizing of cooling system. So, with the help of a proposed building layout and taking into account all possible heat source such as heat gain by individual, heat gain by fluorescent lamp, infiltration and heat gain by ventilation and all other possible heat source will be used to calculate cooling load due to different walls and roofs. At the end of this experiment, we will perform the same work of cooling load for two prominent Indian seasons for a bi-level building which is a part of an institute by using Cooling Load Temperature Difference (CLTD) method.

And results obtained by aforementioned method are made to compare with the standard data obtained from various Fundamental Hand Books, such as by ASHRAE and CARRIER program and result concluded are satisfactory. In the end it is observed through this paper that the cooling requirement of monsoon is about $13 \%$ less in comparison to summer climatic condition

KEYWORDS: Human Comfortness, Cooling Load, CLTD, Air Conditioning
\end{abstract}

Received: Sep 27, 2020; Accepted: Oct 17, 2020; Published: Nov 10, 2020; Paper Id.: IJMPERDOCT202038

\section{NOMENCLATURE:}

CLTD

HVAC

SHGF

RSHG

RLHG

RTHG
Cooling Load Temperature Difference

Heating Ventilation and Air Conditioning

Solar Heat Gain factor

Room Sensible Heat Gain

Room Latent Heat Gain

Room Total Heat Gain

\section{INTRODUCTION}

Nowadays the problem of clean energy generation and its optimum utilization is one of the most severe problems arising Infront of human race. Massive energy wastage and less efficient production by industries and buildings are responsible for this problem [1-2]. 
India the industrial sector is accounted for 44\%(532 billion KWh) of total electricity consumption (1,208 billion KWh) for the year 2019 and about 30\% of this energy input being directed for air conditioning machines [3]. Air-conditioned buildings use roughly twice as much energy as naturally ventilated ones [4]. To minimize energy condition optimal and proper control \& sizing of HVAC systems should be done with exact prediction of the cooling and heating load [5-6]. The designing of HVAC system started around 19th century with first attempt made in 1834 by Dr. Boswell Reid who designed HVAC system for British House of commons. In 1855, Robert Briggs designed and installed, improved HVAC system in U.S. House of Representatives. In 1884, Frank Kidder launched his book named “Architect's and Builder's Handbook”. In 1906, Carrier developed a system which controls the absolute humidity of the air. He patents it and named it "apparatus for treating air". Later, after two years in 1908 he published a psychrometric chart [78]. Fundamental factors which affects the dynamic cooling loads of a construction are external temperature of outdoor vicinity, humidity and duration and orientation of solar radiation [9]. In order to achieve comfort and adequate humidity and air distribution condition in the proposed construction (bi- level building) it is crucial to calculate thermal load for the same. In order to achieve it various building cooling load components taken into account which are; direct solar radiation, transmission load, ventilation/infiltration load and internal load. Calculating all these loads individually and adding them up gives the estimate of total cooling load. The load, thus calculated, constitutes total sensible load. So, in this paper estimated calculation for proposed building will be done using CLTD method

\section{SYSTEM DESCRPITION}

We have decided to perform our study on the double-story building planned to be constructed in Duhai and located at $77.48^{\circ} \mathrm{E}$ longitude and $28.73^{\circ} \mathrm{N}$ latitude in Ghaziabad district of Uttar Pradesh, India which is situate at an altitude of about 214 meters above mean sea level. Ghaziabad has a sub-tropical climate. The tenure between the months of June - September is known as Southwest monsoon during which it will receives moderate rainfall and during retreating of monsoon (Northeast monsoon) rainfall will be very low which usually falls between the months of December - January. Average annual rainfall for the above-mentioned latitude and longitude will be between $780 \mathrm{~cm}$ and $810 \mathrm{~cm} \&$ minimum and maximum temperatures will range between 7 to 47 with a mean minimum and maximum temperature range of 9.8 to 39.2 during coldest and hottest months.

The dimension of the proposed building for which cooling load calculation experiment has to performed is, $110 \times 60 \times 50 \mathrm{~m}$ in size. It has two floors including the ground floor. The exterior walls of building consist of $230 \mathrm{~mm}$ common bricks + air space $+230 \mathrm{~mm}$ common bricks with $13 \mathrm{~mm}$ cement mortar and $26 \mathrm{~mm}$ (13 mm both side) sand cement plaster. The interior walls of building consist of $230 \mathrm{~mm}$ common bricks with 26 (13 mm both side) inch sand cement plaster. The roofs consist of $152 \mathrm{~mm}$ concrete poured in a metal sheet with $13 \mathrm{~mm}$ plaster. The glass windows are present in every room which supported by $12.7 \mathrm{~mm}$ thick frame panel.

Table 1: Specification related to proposed building

\begin{tabular}{|l|l|l|l|}
\hline S.No. & \multicolumn{1}{|c|}{ Specification unit } & \multicolumn{1}{|c|}{ Size/nos. } & \multicolumn{1}{c|}{ Remarks } \\
\hline 1 & $\begin{array}{l}\text { Dimension of the } \\
\text { Building }\end{array}$ & $110 \times 60 \times \mathrm{m}$ & It has 4 walls \\
\hline 2 & Floor & 2 nos. & Both floors have same dimension. \\
\hline 3 & Exterior wall & $230 \mathrm{~mm}$ & $\begin{array}{l}\text { with } 13 \text { mm cement mortar and } 26 \\
\text { sand cement plaster }\end{array}$ \\
\hline
\end{tabular}




\begin{tabular}{|l|l|l|l|}
\hline 4 & Interior wall & $230 \mathrm{~mm}$ & with $26 \mathrm{~mm}$ sand cement plaster \\
\hline 5 & roof & $152 \mathrm{~mm}$ & Concrete \\
\hline 6 & Window & $12.7 \mathrm{~mm}$ thick & Supported by window pane \\
\hline 7 & Rooms & 10 & On each floor \\
\hline
\end{tabular}

\section{METHODOLOGY}

Cooling load or conditioned load is defined as the total heat required to be removed from the space available inside the building in order to bring it at the desired temperature between which is between $21^{\circ} \mathrm{c}-25^{\circ} \mathrm{c}$ and relative humidity around $50 \%$ by using the air conditioning equipment is known as cooling load or conditioned load. This load consists of external as well as internal loads. The equations required to calculate the sensible and latent heat gain are mentioned below. after obtaining their values they are added mathematically using the equation one.

\subsection{Governing Equations}

Sensible Heat Gain through Opaque Surface

$\mathrm{Q}=\mathrm{UA}(\mathrm{CLTD})$ corr

Where

$\mathrm{U}=$ over all heat transfer coefficient $\left(\mathrm{W} / \mathrm{m} 2-{ }^{\circ} \mathrm{C}\right)$

CLTDcorr $=$ cooling load temperature difference $\left({ }^{\circ} \mathrm{C}\right)($ corrected $) \mathrm{A}=$ surface area $(\mathrm{m} 2)$

- $\quad$ Calculation of overall heat transfer coefficient

$\mathrm{U}=$ $\frac{1}{\frac{1}{\mathrm{~h} 0}+\frac{1}{\mathrm{k} 1}+\frac{1}{\mathrm{ka}}+\frac{1}{\mathrm{k} 2}+\cdots \cdots \cdot \frac{1}{\mathrm{hi}}}$

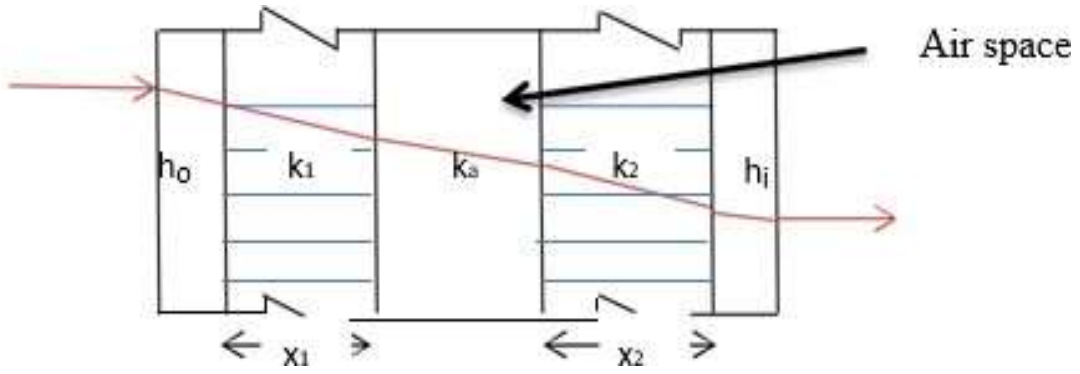

Figure 1: layout of wall of room for proposed building.

- Calculation of corrected CLTD

$\mathrm{CLTD}_{\text {corr }}=(\mathrm{CLTD}+\mathrm{LM}) \mathrm{K}+(25.5-\mathrm{Ti})+(\mathrm{To}-29.4)$

Where

To $=$ outside design temperature $\left({ }^{\circ} \mathrm{C}\right) \mathrm{Ti}=$ inside design temperature $\left({ }^{\circ} \mathrm{C}\right)$

$\mathrm{LM}=$ latitude month correction given table $3.7 \mathrm{~K}=$ correction factor depends on building color.

$\mathrm{K}=1$ for dark color, 0.85 for medium color and 0.65 for light color. 
Heat Gain through Glass

Transmission heat gain through glass

$\mathrm{Q} \square \mathrm{UA}(\mathrm{CLTD})$ corr

By solar radiation

$\mathrm{Q}=\mathrm{A} \times \mathrm{SHGF \operatorname {max }} \times \mathrm{SC} \times \mathrm{CLF}$

Where

SHGFmax $=$ maximum solar heat gain factor $\left(\mathrm{W} / \mathrm{m}^{2}\right) \mathrm{SC}=$

shading coefficient depends on type of sha CLF = cooling

load factor

$\mathrm{U}=$ over all heat transfer coefficient $\left(\mathrm{W} / \mathrm{m} 2-{ }^{\circ} \mathrm{C}\right) \mathrm{CLTD}=$ cooling load temperature difference $\left({ }^{\circ} \mathrm{C}\right)$

\section{Heat Gain from Occupants}

Sensible heat gain from occupants

Qs, person $=\mathrm{q}_{\mathrm{s}}$, person $\times \mathrm{N} \times \mathrm{CLF}$

Latent heat gain from occupants

Q1, person $=\mathrm{ql}$, person $\times \mathrm{N}$

$\mathrm{q}_{\mathrm{s}, \text { person }}=$ sensible heat gain/person $(\mathrm{W})$

$\mathrm{q}_{1, \text { person }}=$ latent heat gain/person

$\mathrm{N}=$ total number of people present in condition space CLF $=$ cooling load factor

\section{Heat Gain from Lighting Equipment}

Qlight $=$ Total wattage of light $\times$ Use factor $\times$ Allowance factor

Where

Use factor $=$ the ratio of actual wattage in use to installed wattage

Allowance factor $=$ is used in the case of fluorescent light to allow for the power used by the ballast. Its value is taken as 1.25

\section{Heat Gain from Electric Equipment}

$\mathrm{Q}_{\text {equipement }}=$ Total wattage of equipment $\times$ Use factor $\times$ CLF

Where

$\mathrm{CLF}=1.0$, if operation is 24 hours or of cooling is off at night or during weekend

\section{Heat gain due to Infiltration}


Amount of infiltrated air $($ Vinf $)=\frac{\text { volume of space } \times \mathrm{Ac}}{60} \mathrm{~m}^{3} / \mathrm{min}$

The sensible heat gains due to the infiltration

$$
\text { QS,inf }=20.44 \times \operatorname{Vinf} \times(\text { To }-\mathrm{Ti}) \text { Watt }
$$

latent heat gain due to the infiltration is given by

$$
\mathrm{QL}, \inf =50000 \times \operatorname{Vinf} \times(\text { Wo }- \text { Wi }) \text { Watts }
$$

Where

To and $\mathrm{Ti}=$ Outside and inside design temperature respectively $\left({ }^{\circ} \mathrm{C}\right)$

Wo and $\mathrm{Wi}=$ specific humidity of outside and inside at conditioned space $(\mathrm{kg} / \mathrm{kg}$ of dry air)

After determining all the above values, we just need to insert them in final equations to derive the load requirement for proposed building. RSHG stands for room sensible heat gain and RLHG stands for room latent heat gain whose magnitude is obtained by summation of their respective heats. RSHG is the summation of sensible heat gain through walls, floors and ceilings \& sensible heat gain through glasses \& sensible heat gain due to occupants \& sensible heat gain due to infiltration air \& sensible heat gain due to ventilation \& sensible heat gain due to lights and fans. On the other hand, RLHG is the summation of latent heat gain due to infiltration and latent heat gain due to ventilations latent heat gain from persons and latent heat gain due to appliances.

$$
\mathrm{RTHG}=\mathrm{RSHG}+\mathrm{RLHG}(\mathrm{i})
$$

Room sensible heat factor is defined as the ratio between thee room sensible heat to the room total heat. Mathematically, room sensible heat factor
$\mathrm{RSHF}=$$$
\frac{R S H G}{R S H G+R L H G}
$$$$
\underline{R S H G}
$$ RTHG

\subsection{Assumptions}

During the performing of this analysis the assumptions taken into consideration are mentioned below.

- various flow rate such as heat flow rate, air flow rate is taken constant.

- mass transfer is not taken into consideration,

- buiding walls are treated as smooth and regular surface.

- changng effect of solar radiation due to clouds is not taken into account.

\section{RESULT AND VALIDATION}

For all the ten rooms of the proposed two floor building on each floor RSHG, RLHG, RTHG and SHR is calculated and by dividing RTHG by 3500 total loads in tons is obtained. Each room is treated as the separate system and the cooling load details for all rooms for summer month are shown in table 1 whereas for monsoon month, they are shown in table 2.The value for the entire floor is obtained by summation of each of the value of different kinds of room and for the final result of cooling load is the obtained summation value of load is multiplied by 2 which gives the total load for the bi-level proposed 
building.

Table 2: Total load of proposed building for the summer month

\begin{tabular}{|l|c|c|c|c|c|}
\hline \multicolumn{1}{|c|}{ Room name } & RSHG & RLHG & RTHG & $\begin{array}{c}\text { Total load } \\
\text { (tons) }\end{array}$ & SHR \\
\hline $\begin{array}{l}120 \text { seated lecture } \\
\text { room }\end{array}$ & 27000.65 & 11620.30 & 38620.95 & 11.03 & 0.69 \\
\hline Washroom & 5024.87 & 1471.11 & 6492.98 & 1.85 & 0.77 \\
\hline Placement office & 4948.50 & 1240.61 & 6189.11 & 1.76 & 0.79 \\
\hline Innovation room & 7059.59 & 1993.45 & 9053.04 & 2.58 & 0.77 \\
\hline Professor room & 5564.00 & 1521.06 & 7085.06 & 2.02 & 0.78 \\
\hline $\begin{array}{l}120 \text { seated lecture } \\
\text { room }\end{array}$ & 27000.65 & 11620.30 & 38620.95 & 11.03 & 0.69 \\
\hline Alumni relation & 11862.30 & 2706.46 & 14568.76 & 4.16 & 0.81 \\
\hline Alumni visitor & 16445.23 & 4845.64 & 21290.87 & 6.08 & 0.72 \\
\hline store & 16513.61 & 4858.07 & 21371.68 & 6.10 & 0.77 \\
\hline Meeting room & 15921.23 & 4807.58 & 20728.81 & 5.92 & 0.76 \\
\hline Summation & 137340.6 & 46684.6 & 184025.2 & 52.53 & $0.74($ average) \\
\hline
\end{tabular}

Table 3: Total load of proposed building for the monsoon month

\begin{tabular}{|l|c|c|c|c|c|}
\hline \multicolumn{1}{|c|}{ Room name } & RSHG & RLHG & RTHG & $\begin{array}{c}\text { Total load } \\
\text { (tons) }\end{array}$ & SHR \\
\hline $\begin{array}{l}\text { 120seated lecture } \\
\text { room }\end{array}$ & 21047.32 & 13971.62 & 35018.94 & 10.05 & 0.60 \\
\hline Washroom & 4016.25 & 1833.82 & 5850.07 & 1.67 & 0.68 \\
\hline Placement office & 3461.04 & 1693.52 & 5154.56 & 1.47 & 0.67 \\
\hline Innovation room & 4812.03 & 2644.30 & 7456.33 & 2.13 & 0.64 \\
\hline Professor room & 3712.95 & 1983.76 & 5696.71 & 1.62 & 0.65 \\
\hline $\begin{array}{l}\text { 120seated lecture } \\
\text { room }\end{array}$ & 21047.32 & 13971.62 & 35018.94 & 10.05 & 0.60 \\
\hline Alumni relation & 8854.96 & 3634.56 & 12489.52 & 3.56 & 0.70 \\
\hline Alumni visitor & 11872.03 & 6527.28 & 18399.31 & 5.25 & 0.65 \\
\hline store & 11737.88 & 6464.48 & 18202.36 & 5.20 & 0.64 \\
\hline Meeting room & 11145.50 & 6448.64 & 17594.14 & 5.02 & 0.63 \\
\hline average & 101707.2 & 59173.5 & 160880.7 & 46.02 & $0.63($ average) \\
\hline
\end{tabular}




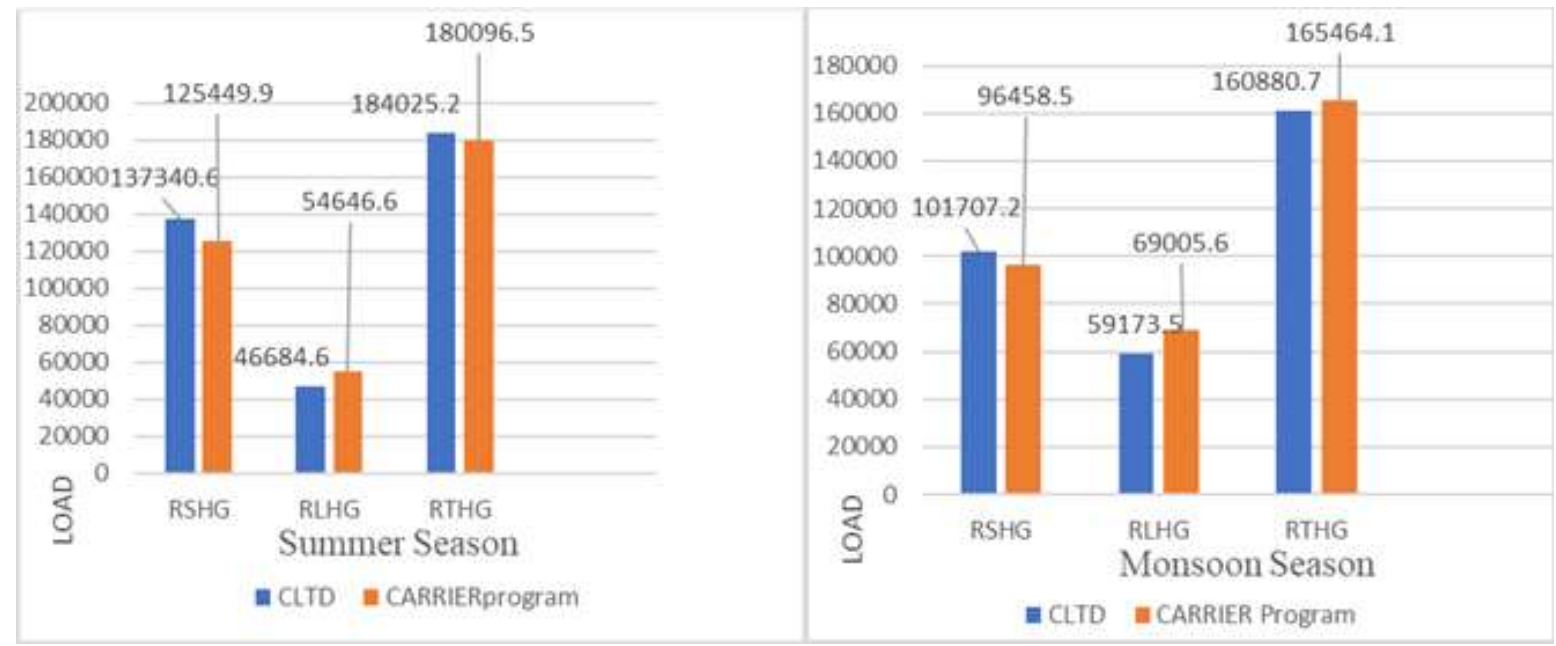

Figure 2: Comparison between cooling load by CLTD and carrier program for different season

All the above values are again obtained using the carrier program of organization named carrier HVAC system design and the results obtained by this program are made to compare with CLTD method. The comparison of the both of their average values is shown in the graph below. From the below graph we conclude that value of RSHG are less in program than by CLTD method but the other two values are more for program than the CLTD method. The variation in value are 9.04\% $15.71 \%$ and $2.1579 \%$ for RSHG, RLHG and RTHG respectively for summer season but for the monsoon season the variation for RSHG, RLHG, RTHG is $5.29 \%, 15.31 \%, 2.80 \%$ respectively.

\section{CONCLUSIONS}

The cooling load calculation described in the present paper is simply based on the rule of thumb. It may be called a computer version of cooling load estimation form. But surprisingly enough it gives very reliable results, which are almost the same as those obtained by the sophisticated and costly commercial software developed and marketed by the renowned MNCs. It is very easy to use and requires quite few numbers of data input. It is also capable of being used as a good tool to make thorough investigations of different building parameters and its orientation before starting the construction. With help of calculations following inferences can be drawn

- It is clear that the cooling load (in tons) for the proposed building in the summer season in will be 105.06 tons and for the monsoon season it will be 92.04 tons

- Cooling requirement of proposed building in monsoon is about $13 \%$ less in comparison to summer climatic condition

- The average sensible heat ratio of the building is 0.76 for summer and 0.637 for monsoon. It shows that the cooling load calculation is properly done with well accounted of latent heat came from the people and infiltration, especially in humid weather

- In regard to future scope any programming language can be used to write the code using above mathematical equations which will reduce the hefty work and easily calculate cooling load for any proposed building.

\section{REFERENCES}

1. Phebe Asantewaa Owusu, Samuel Asumadu-Sarkodie (2016). A review of renewable energy sources, sustainability issues and climate change mitigation. 
2. Cooling load calculation manual prepared by the American Society of Heating, Refrigerating and Air-Conditioning Engineers, Inc., U.S. Department of Housing and Urban Development.

3. Faisal Fahad AL-Musa (2018). Energy savings of a recommended residential air conditioning incentive program in Saudi Arabia.

4. LeilaMoosavi, Norhayat iMahyuddin, NorafidaAb Ghafar, Muhammad Azzam Ismail (2014). Thermal performance of atria: An overview of natural ventilation effective designs.

5. Abdullatif E.Ben-Nakhi, Mohamed A.Mahmoud (2004). Cooling load prediction for buildings using general regression neural networks.

6. Mohamed Elhelw (2016). Analysis of energy management for heating, ventilating and air- conditioning systems. [7]. Anurag Kumar Singh, Akanksha Mishra, K.K. Dubey (2016). Cooling Load Estimation for Library. [8]. C. Mao, "Peak Heating/Cooling Load Design Methods", 13th Conference of International Building Performance Simulation Association, Aug 2013, pp. 2628.[9]. ZhaosongFang, Nan Li, Baizhan Li, Guozhi Luo,Yanqi Huang (2014). The effect of building envelope insulation on cooling energy consumption in summer

7. ASHRAE, Handbook of Fundamentals, Ch. 28. American Society of Heating, Refrigerating and Air-Conditioning Engineers, U.S.A. (1997).

8. A Bhatia, HVAC Made Easy: A Guide of Heating and Cooling Load Estimation, PDH online course M196 (4PDH).

9. Handbook of Air Conditioning System Design /Carrier Air Conditioning Co. by Carrier Air Conditioning Pty. Ltd.

10. Anderson B., Wayne P. and Ronald K., "The impact of building orientation on residential heating and cooling", Energy and Buildings, 1985; 8; 205-224.

11. Al-Rabghi,O. and Khalid A. ,"Utilizing transfer function method for hourly cooling load calculations" Energy Conversion and Management, 1997; 38; 319-332

12. Shariah,A., Bassam S., Akram R. and Brhan T.," Effects of absorptance of external surfaces on heating and cooling loads of residential buildings in Jordan" Energy Conversion and Management, 1998; 39; 273-284.

13. Kulkarni K., P.K. Sahoo and Mishra M., "Optimization of cooling load for a lecture theatre in a composite climate in India" Energy and Buildings, 2011; 43; 1573-1579.

14. Suziyana M. D., Nina S. N., Yusof T. M. and. Basirul A. A. S., "Analysis of Heat Gain in computer Laboratory and Excellent Centre by using CLTD/CLF/SCL Method” Procedia Engineering, 2013; 53; 655 - 664.

15. Hani H. Sait, "Estimated Thermal Load and Selecting of Suitable Air-Conditioning Systemfor a Three-Story Educational Building” Procedia Computer Science, 2013; 19; 636- 64

16. Suqian Y., Jiaping L., Ge Xiangrong and Xiang H., "The Research of Cooling Load and Cooling Capacity Calculation Methods of Spinning Workshop” Procedia Environmental Sciences, 2011; 11; 597 - 603.

17. Foudaa A., Melikyan Z., Mohamed M.A. and Elattar H.F., "A modified method of calculating the heating load for residential buildings" Energy and Buildings, 2014; 75; 170-175.

18. Duanmu L., Wang Z., Zhai Z.and Xiangli L., “A simplified method to predict hourly building cooling load for urban energy planning” Energy and Buildings, 2013; 58; 281-291.

19. Christian A., Gueymard and Thevenard D, "Monthly average clear-sky broadband irradiance database for worldwide solar heat gain and building cooling load calculations "Solar Energy, 2009; 83; 1998-2018 